\title{
III. On the alleged Greek traditions of the deluge
}

\section{Rev. John Kenrick M.A.}

To cite this article: Rev. John Kenrick M.A. (1834) III. On the alleged Greek traditions of the deluge , Philosophical Magazine Series 3, 5:25, 25-33, DOI: 10.1080/14786443408648394

To link to this article: http://dx.doi.org/10.1080/14786443408648394

册 Published online: 01 Jun 2009.

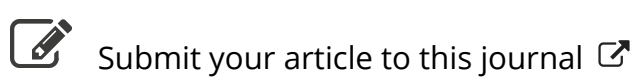

Џ Article views: 3

Q View related articles $\sqsubset$ 
however, by an exactly similar result in regarding the phænomena of our own and other sea cliffs, acted on by the sea, which will form the subject of another paper, all doubt on this head that may have existed must surely be for ever removed.

\section{On the alleged Greek Traditions of the Deluge.} By the Rev. John KenRICK, M. A.

[Continued from vol, iv. p. 420 ; and concluded.]

$\mathbf{W}^{\mathrm{E}}$ $\mathrm{E}$ have now reached the time when the Greeks, having been brought into much more extensive and leisurely intercourse with Assia than they had enjoyed before the time of Alexander, had the opportunity of comparing their own fables with those of the Asiatics, and of remodelling or adding to their own, in order to give them a more imposing appearance, or to maintain the claim of originality in everything, to which in earlier times they were far from pretending, and which is, indeed, without any foundation in history. We cannot, therefore, appeal with confidence to what we find in Greek authors from this time forward, even as proving the existence of a Greek tradition; still less can Ovid's version of the story be appealed to. "A mesure," says Cuvier, " que l'on avance ver's des auteurs plus récens, il s'y ajoute des circonstances de détail qui ressemblent davantage à celles que rapporte Moïse. Ainsi Apollodore donne à Deucalion un coffre pour moyen de salut; Plutarque * parle des colombes par lesquelles il cherchait à savoir si les eaux s'étaient retirées, et Iucien $\dagger$ des animaux de toute espèce qu'il avait embarqués avec lui," etc. Yet he had written in a preceding page, "Pour peu que l'on suive la manière dont le déluge de Deucalion a été introduit dans les poëmes des Grecs et les divers détails dont il s'est trouvé successivement enrichi, il devient sensible que ce n'était qu'une tradition du grand cataclisme, altérée et placée par les Hellènes á l'époque où ils plaçaient aussi Deucalion." If we find ingredients in the stream at a distance from the source, which it has not when examined nearer to the spring, the natural conclusion would seem to be that it has acquired them on its way, not that they were there from the first, in some mysterious state of delitescence.

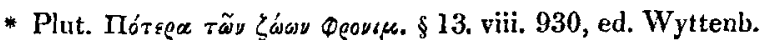

+ It is doubtful whether Lucian were the author of the treatise $D e D \epsilon t$ Syrâ, in which this mention of the flood occurs: what is more important to our purpose is that the writer, whoever he was, probably was an Asiatic Greek.

Third Scries. Vol. 5. No. 25. July 1834. 
The traditions of the flood of Ogyges will not detain us long. Even his name, as a king of Attica, does not occur in any extant author before the time of Alexander, and for most of what we know of him we are indebted to the Christian chronologers. A passage in Eusebius, Prap.Evang. x. p. 10. might lead us to conclude that the flood in his time had been mentioned by Acusilaus, $i . e$. in the beginning of the 5th cen-

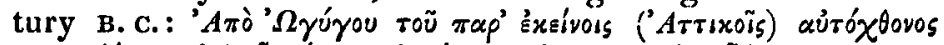

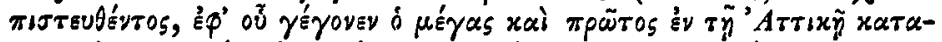

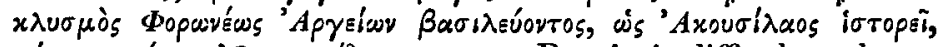

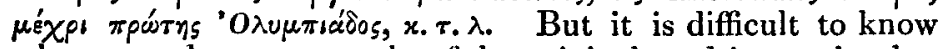
what were the exact words of the original, and it may be that the mention of the deluge proceeds from Eusebius himself, especially as Syncellus has the following passage, (p. 119. ed.

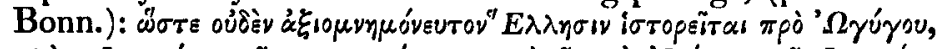

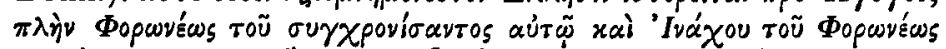

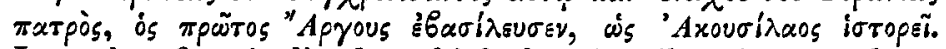
I am therefore inclined to think that Acusilaus is properly to be considered only as an evidence to the dominion of Phoroneus at Argos; or at most to the synchronism between him and Ogyges. The name of Ogyges never occurs in Attic poetry, nor is there any trace of him in the remains of Attic art. Philochorus, who wrote his Atthis about 260 B.c. seems to speak of Ogyges as king of Attica, according to the quotation from Julius Africanus in Syncellus, (p. 281. ed.

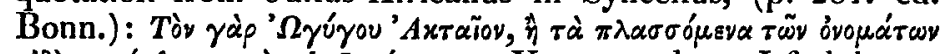

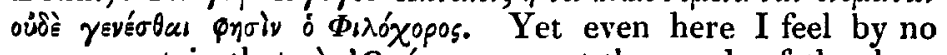
means certain that $\tau \dot{\partial} \nu^{\prime} \Omega \gamma^{\prime} \gamma^{\prime}$ ov are not the words of the chronologer*. There is no mention of Ogyges in the Parian marble, which was engraved about the time when Philochorus published his Atthis.

* If any one should think that this is an attempt to get rid unfairly of a witness, let him see what a license this same chronologer allows himself.

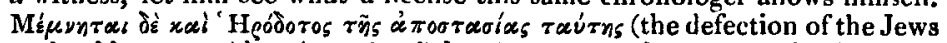

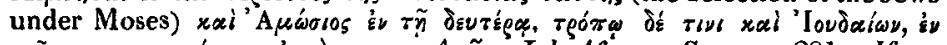

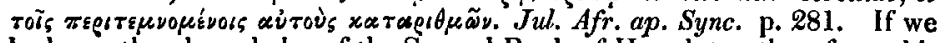
had no other knowledge of the Second Book of Herodotus than from this passage, could we have ventured to doubt whether the name of Amosis, if not of the Jews, occurred in it? Heyne, Apoll. vol. ii. p. 320, on the strength of this passage in $J u l . A f r$., supposes that something has dropt out of the text of Apollodorus, at the beginning of 3. 14. in which, if we had it, we should find something about Ogyges. Yet the actual commence-

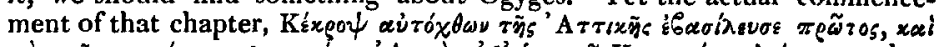

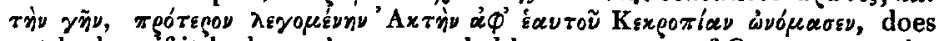
not look as if it had ever been preceded by an account of Ogyges, a predecessor of Cecrops. With the same inaccuracy Syncellus (i. 238.) makes Plato in the Timaus speak of "the flood in the time of Ogyges," though Plato never mentions his name. 
I have given in the Philological Museum, ii. p. 348, my reasous for thinking that the name and story of Ogyges belong properly to Bootia. Whether I am right or not in the interpretation which I have given to his name, the fact that traditions respecting him were connected with Bœotia, and that we have no proof that they were so with Attica, remains the same. As to his flood, till some more decisive passages are produced than those which have been given above, I must be allowed to doubt whether we have any proof that either in Bœotia or Attica there was any tradition respecting it. Pausanias, says, Boot. 5., that 'Thebes derived the name of Ogygian, which many of the poets had given it, from an autochthon, Ogygus, king of the Hectenes, and that this people

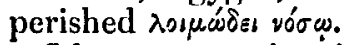

I have now to inquire how the popular belief among the Greeks upon the subject of a flood in the time of Deucalion is to be accounted for. Three suppositions may be made, The progenitors of the Hellenes brought with them from Asia a tradition of the flood of Noah, which they localized in their own country, by attributing it to Thessaly. This is the common opinion; and it is the more easily adopted because, as we know nothing whatever of the tribes from whom the Greeks originated, we pass per saltum from Thessaly to the plain of Shinar, and nothing seems simpler than that they should preserve a tradition of a recent and impressive event. But let us consider chronology a little. According to the Hebrew text the deluge is placed about 2300 B.c. ; but historical inquirers are beginning to feel the inconvenient limitation of time which this occasions, and adopt the Septuagint reckoning, which will carry it up to 3500 B.c. Now we have not found any traces of this tradition in Greece earlier than the commencement of the 5th century before Christ. Here is then a period of 3000 years, during which we must suppose it to have been preserved in the minds of a race who, if their own tradition about Prometheus is to be believed, (and it is found in earlier authors than that of Deucalion,) had not even the use of fire among them. It would be too much to say that such a transmission is impossible. Those who believe that Ammonian and $\mathrm{Cu}-$ thean priests marched from Chaldæa to all parts of the world, bearing diluvial traditions and helio-arkite symbols, may not even find it improbable; but let the linguist and the ethnographer reflect on the changes and vicissitudes through which the ancestors of the Hellenes must have passed, and they will be startled, I think, at the demand made upon their belief. Nothing could make the preservation of a tradition in these circumstances credible, but such a close resemblance as preE 2 
cluded the idea of accidental coincirlence, manifesting itself at a time when there could be no communication with a foreign source. We have not found either of these conditions fulfilled in our inquiry into the traditions of Deucalion.

The next hypothesis which suggests itself is that they are the real reminiscences of some local flood, such as a country abounding with lakes and mountains, bordered by the sea, and exposed to earthquakes, must often have undergone. It is certain that the Greeks had no tradition of a general deluge. Apollodorus, whose description of the flood of Deuca-

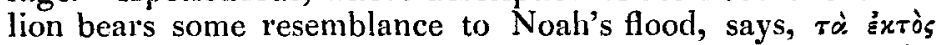

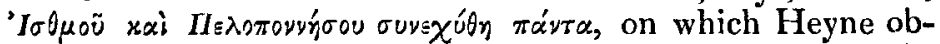
serves, " in Peloponneso diluvii memoria nulla," which is substantially true, although Dionysius of Halicarnassus (i. 61.) mentions that some of the Pelasgians left Arcadia for Samothrace in consequence of a flood which deprived them of part of their land. This is also true of Attica, though Pausanias speaks of a chasm (i. 18. 43.) in the temple of Jupiter, through which the water of Deucalion's flood (i் $\pi$ or $b$ pia) had run off. 'This may seem a presumption in favour of a real tradition of an inundation produced by an earthquake, or some similar cause. Yet even in this modified form, the opinion of a real tradition appears to be open to many of the objections urged against the former hypothesis. If chronology is to be applied to these matters at all, Deucalion's flood cannot be placed later than the 15 th century before Christ: we find the first mention of it in the 5th. We must not judge of the probability of such a transmission by the fact of traditions having reached our own times from those of the Roman empire: the use of writing has never been lost in Europe. Besides, all the circumstances of the story are evidently fictitious. No inundation could have floated or driven Deucalion to the top of Parnassus without deluging all the low lands of Greece; and it will then require to be accounted for, how this event has left no tradition in the other parts which must have suffered from it. If we take away from the story Deucalion and Pyrrha, the ark, the resting on Mount Parnassus, the reproduction of the human race by the casting of stones, what remains to be the matter of a tradition? The simple fact of an inundation,- - a natural phænomenon which the imagination can multiply and magnify as much as it pleases, and place in any age it thinks fit. The only reason for admitting such an extraordinary transmission of a fact, through ages which have preserved no memorials of their own history, would be the impossibility of conceiving how such a thing should have been invented, if not true. But unless 
the event, though within the laws of nature, were beyond men's knowledge and experience of them, the more likely it was to happen, the more easy it was to suppose it happening, to adorn it with circumstances, and to fix it to time and place. The vulgar, too, draw much more liberally on extraordinary causes to explain appearances, than a philosopher allows himself to do.

If we are to receive the account of Deucalion's flood as the tradition of a real occurrence, it will be difficult to say why we should not do the same with regard to other Greek fables. But of what real occurrence is the combustion of the world by Phathon, a tradition; or the submersion of the island Atlantis; or the splitting of the continent Lyctonia into the islands of the Mediterranean*? Although Sicily was to the Greeks " the Threepointed Islandt," from the earliest time in which it is named by them, and Scylla and Charybdis appear in the voyage of Ulysses, must we suppose that there was a real tradition of its having been a part of Italy, separated from it at Rhegium $\ddagger$ by an earthquake?

We seem, therefore, to be brought to the third supposition, that there is nothing historical in the flood of Deucalion, and that all the circumstances which we find in Greek authors respecting it, previously to the time when they may have mixed their own accounts with those of foreigners, are fictitious. But fictions must have a determining cause, and those which relate to physical events generally have this cause in physical appearances, popularly interpreted. Thessaly, the scene of Deucalion's flood, and Bœotia, to which some, though fainter, traditions of a similar event may have been attached, were both countries which, from their structure, were peculiarly liable to inundations. We are so accustomed to associate ideas derived from Scripture with the words flood, deluge, cataclysm, that we transfer them to other ancient history, and suppose that they imply events of equal magnitude. But any overflowing of a river which swept away what was upon its banks, was to the

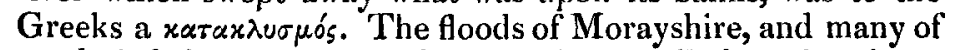
much inferior extent, would have been called so by them. The physical structure of Thessaly rendered it, of all parts of Greece, the most natural scene of an inundation which should dislodge mankind from their customary abodes. The whole drainage of the valley which is inclosed by Pelion, Ossa, and Olympus, Pindus and Othrys, takes place through the single

* Orph. Argon. 1283 seq.

+ At least if the eginoxin of Homer (Od. $\left.\lambda^{\prime}, 106 . \mu^{\prime}, 127.\right)$ be the Trinacria of later geography, which can hardly be doubted. See Uckert, I. i. p. 21 .

‡ Strabo, i. p. 88, ed, Oxon. 
outlet of the Vale of Tempe*; and it was not necessary to have the eye or the imagination of a geologist, in looking at this singular chasm, to perceive its use, and revert to the time when no such opening existed, and the waters of the Peneius, the Enipeus and the Apidanus must have discharged themselves into a lake covering the greater part of Thessaly. The well-known passage in Herodotus (vii. 129.) shows how early such an idea had been formed. It was then a hóros that all Thessaly had been once a lake, and that Neptune, i.e. an earthquake, had opened the passage by which the lake was drained. That there was any real tradition of a time prior to the opening of Tempe, I do not believe, for the very first glimmerings of Grecian history show us Thessaly peopled by various tribes, whose seats were on the banks of the rivers; but if men speculated upon the condition of things which must have preceded the opening of the outlet, and put their speculations into the form of a $\lambda$ óros, why might they not also speculate on the consequence of a sudden stoppage of the outlet, or of a fall of rain so copious and long continued that the narrow passage of the Peneius could not afford it

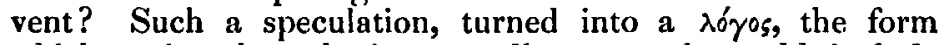
which ancient hypothesis generally assumed, would include all that belongs to the flood of Deucalion, separated from foreign admixtures. I have already mentioned that, as related by Apollodorus, the story appears to contain portions of two distinct mythi. Deucalion was probably at first only the patriarch of the Hellenic tribe ; but as they had their original seat in Thessaly, and affected to consider the commencement of their own history as the commencement of civilization, the flood of Thessaly and the person of Deucalion would naturally be connected together + .

Boeotia, like Thessaly, is exposed, from its physical structure, to suffer from inundations. Its principal river, the $\mathrm{Ce}$ phisus, terminates its course in the lake Copais, the waters of which have no superficial outlet to the sea, and would soon lay the whole country under water, were it not that they find

- See Hawkins in Walpole's Memoirs of Greece, vol. i. p. 528.

+ Mr. Keightley in his Mythology, p. 268, derives Deucalion from $\delta \varepsilon v \omega$ (whence $\delta \varepsilon v^{\prime} \times y_{s}$ ) to wet, and perhaps $\alpha \lambda_{5}$ the sea. But besides the difficulty that $\delta$ súxns does not appear to mean wet, why should Deucalion, who rode dry in his $\lambda \alpha \rho^{y} \infty \xi \xi$ and whose flood was one of rain water, be called by a name which means dipped in the sea? What if $\Delta \varepsilon u r e \lambda i \omega$ and the cugnate form $\Delta$ surxatos (Heyne ad $I l, v^{\prime} .307$.) were derived from $\Delta \varepsilon v_{s}$, the old form of $Z_{\varepsilon} \dot{u}_{5}$, and $x \notin \lambda \varepsilon=s$ ? The commencement of religion among the Hellenes would naturally be ascribed to the patriarch of the race, and he was not only reputed to have founded Dodona in Thesprotia and to have sacrificed to Jupiter on his deliverance, but even to have founded altars to the twelve great gods,-Apollod. 1.7. 2. Eudocia, p. 108. 127. 
a vent by a subterraneous passage in the cavernous limestone, and discharge themselves into the Euripus at Larymna. This subterraneous channel was liable to be stopped, especially by earthquakes, which were frequent in Bœotia, and the consequence was, an inundation of the country around the lake. In the time of Alexander the Great, an engineer, Crates of Chalcis, was employed to open the obstructed passage, and the shafts which he sunk down upon it may still be traced along its course*. In a report addressed to Alexander, preserved by Strabo, he says that many districts had already become dry, and the sites of ancient towns had reappeared. According to some, Eleusis and Athens had stood here in the time of Cecrops, who was king of Bœotia, then called Ogygia. Pausanias again (ix. 38.) relates that Hercules had stopped the subterraneous passage, in order to flood the fields of the Orchomenians. The singular condition of this lake, and the variations to which it was subject in winter and summer, to say nothing of extraordinary rains and accidental stoppages of the outlet, invited the fancy to frame wonderful tales respecting it, and we may surely account for the flood of Ogyges without having recourse to that of Noah. The wonderful coincidence in time, which made Cuvier (p. 85.) conclude that the former one must have been derived from the latter, really depends on a date arbitrarily fixed by the chronologers + .

I will mention one other opinion $f$, which connects the stories of destruction by water and fire together, and supposes them to have originated in the observation, that at the different seasons of the year, more strongly discriminated in southern climates than in our own, the principles of moisture and heat alternately predominate, whence arose the notion that the annus magnus, which comprehended a vast cycle of celestial phænomena and terrestrial changes, included both

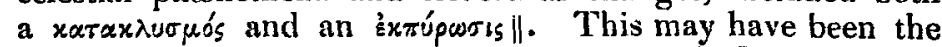
origin of the Egyptian doctrine and of that of Heraclitus and the Stoics; it may have had a share in producing the story of Phaethon; but the deluge and the conflagration do not appear to me to have had any connexion with each other in the popular conceptions of the Greeks, which alone it has been my object to examine.

The result of this examination will not, I hope, appear altogether unimportant. It is not difficult to foresee that the

* Walpole, i. p. 303. seq.

+ Cuvier quotes Varro as placing the deluge of Ogyges 400 years before Inachus; but it does not appear from the passage in Censorinus (21.) that Varro mentioned the name of Ogyges.
\pm Bohlen, Altes Indien. i. p. 219 .
II Censorinus 18. 
time is approaching, when geologists will no longer refer all marks of the superficial action of violent currents of water on the earth, subsequent to the consolidation of its newest strata, to one flood, limited in its time and strictly defined in its circumstances, as the Mosaic deluge is; but will be compelled to acknowledge that their science points to prolonged, repeated and multiform operations of diluvial currents*. "The popular view of this subject derives a strong support from the belief that other nations have a real tradition of the Mosaic deluge, and that something like a chronological coincidence between them can be established. If this opinion has been shown to be unfounded, scientific inquiry into the phænomena of diluvial agency on the earth's surface will not be embarrassed by the necessity of making its results conform to those of another branch of knowledge.

I will only observe in conclusion, that the Mosaic account of the Deluge appears to me to bear many of those marks of a tradition of high antiquity, which we have sought in vain in the Greek legends of Deucalion. It is found in the book which the Jews have always regarded as the most ancient of their sacred writings, and it exhibits traces, as critics of the first name assure us, of being itself a document yet older than the book in which it has been incorporated. It does not correspond with the traditions or speculations of the Egyptians or the Phœnicians, but in a remarkable manner with those of the people of Mesopotamia and Chaldæa, countries with which the Jews were connected by the origin of their nation. Had they framed it for themselves, it would have been natural for them to refer it to their own country, to have made Noah build his ark in the forests of Lebanon, and the ark rest on the top of Hermon or of Carmel. Instead of this, everything is referred to the valley of the Euphrates and the Tigris. 'I'he cypress of which the ark was built was the only wood fit for ship-building which this region afforded + ; the bitumen with which it was covered was the product of its asphaltic springs $\ddagger$; the mountain on which it rested is that from the vicinity of which the Tigris and Euphrates rise, and which looks down

* [See Prof.Sedgwick's Anniversary Address to the Geological Society in 1831, Phil. Mag. arid Annals, N.S. vol. ix. p. 313; and also Mr. Greenough's late Address to the same body, in our present Number.-EDit.]

+ The testimony of Arrian, ix. 19., that the cypress was the only wood fit for ship-building of which there was any considerable quantity in Assyria, with the cotrespondence of the consonants in 794 and $x y \pi \alpha$ coroos, is, I think, decisive in favour of the opinion of Bochart and Celsius that the gopher wond is the cypress. [See Mr. Beke's paper on this subject, in Lond. and Edinb. Phil. Mag. vol. iii. p. 103. - Evir.]

$\mp$ Herod. i. 179. [See Mr. Beke's Remarks on Mr. Carter's paper, in our Number for April last, or vol, iv. p. 280.-EDIT.] 
over the countries through which they flow; the plain of Shinar is the scene in which the history of mankind recommences when the Deluge is over. Unless we could suppose the Pentateuch to have been written after the captivity, and the Jews to have begun their history with the borrowed traditions of their oppressors, we must admit that these things were subjects of belief in the family of Abraham from the time when he left his original abode in Ur of the Chaldees*.

IV. Remarks on the Atomic Constitution of Elastic Fluids. By William Charles Henry, M.D., F.R.S.†

THE following remarks, suggested by that portion of Dr. Prout's Bridgewater Treatise which is devoted to the most comprehensive generalizations of chemical philosophy, are proposed with considerable hesitation, from their not according with the views of that profound writer. But it must also be borne in mind, that the theory of atomic combination adopted by Dr. Prout differs itself, most materially, from that originally framed by the author of the atomic philosophy, and still held by him, as well as by the majority of British chemists. These differences, as far as they respect first principles, may be comprehended in the two following propositions :

ist, That equal volumes of all gaseous bodies contain, under the same temperature and pressure, the same number of self-repulsive molecules.

2nd, "That the self-repulsive molecule, as it exists in the gaseous form, does not represent the ultimate molecule, but is composed of many of them."

1st, The idea that the particles of all gaseous fluids are placed at the same distances from one another, and consequently that a given space contains in all the same number of molecules, seems to have occurred about the same time to MM. Ampère and Avogadro. It was published by the former, so early as the year 1814, in a letter addressed to Count Berthollet, but merely as the most probable hypothesis of the constitution of elastic matter $\neq$. It was subsequently revived by Dumas, and has been recently maintained and illustrated by his pupil M. Gaudin§. Dr. Prout had arrived at the same

- [Our correspondent Mr. Beke, in the Appendix to his recently published work, entitled Origines Biblice, has shown reasons for the belief that the Flood, though universal with respect to mankind, was merely local with respect to the globe itself; a view of the subject which, if fully substantiated, would tend to relieve it from much of the difficulty in which it is at present involved.-EDit.]

+ Communicated by the Author. $\$$ Ann. de Chimie, tom. xc. p. 47.

$\$$ Ann. de Chimie et de Phys., tom. lii. p. 113.

Third Series. Vol. 5. No. 25. July 1834. 